\title{
The Acta Ethnographica Hungarica and the International Academic Community - Editorial
}

\author{
Ágnes Fülemile \\ Institute of Ethnology, RCH, Hungarian Academy of Sciences, Budapest
}

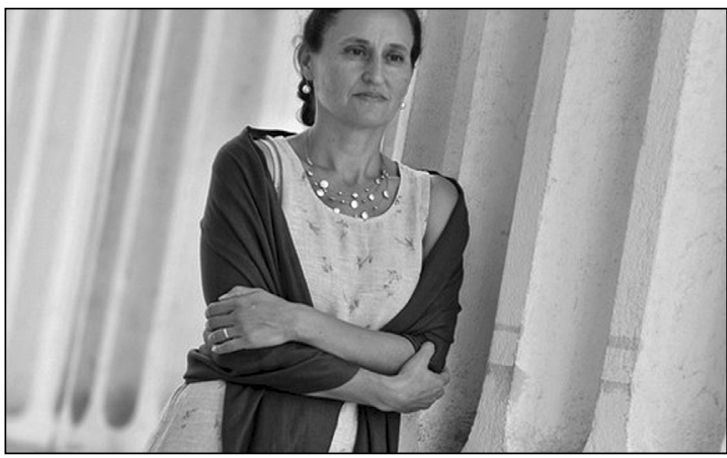

Our journal, the Acta Ethnographica Hungarica, has been established 67 years ago, in 1950, by the Hungarian Academy of Sciences with the primary goal of creating an international 'interface' to represent and mediate the best results of Hungarian scholarship to foreign academic audiences. It was also intended to provide a forum for scholars with an interest not only in the region of Hungary and Central Europe but also in the larger Eurasian continent, as well as in the more distant terrains of ethnologic fieldwork. Only five years after the end of the Second World War and very soon after the Communist takeover, Hungary wished to put herself back onto the map of international scholarship. Although the founding editor, Gyula Ortutay, had an acknowledged career as a scholar, he became a politician in important positions and gained the necessary influence to shape academic life as well. The new journal, with a gesture to reference the classical roots of sciences, was named with a Latin title: Acta Ethnographica Academiae Scientiarium Hungaricae. ${ }^{1}$ Contrary to the political pressure of the time, it was intended to address not only the Eastern bloc, but also the Western academic community with whom Hungarian scholars maintained vivid connections before the late 1940s takeover. The four languages of the journal (English, French, German and Russian) had clearly expressed the intent to reach and interact with the Western scholarly audience as well.

Altogether there have been 60 annual volumes published in quarterly and later in semi-annual issues, and there were some extra issues on special themes added to the

\footnotetext{
${ }^{1}$ The title of the journal was later simplified to Acta Ethnographica Hungarica with the 1991/1992 volume.
} 
list. The editors of the journal were leading scholars who had important contributions to various subfields of the discipline. The consecutive editors-in-chief obviously had a decisive role in shaping not only the character of the journal, but also the institutional background and the study directions of the discipline as well. Besides Gyula Ortutay, who in 1967 became the founder of the Institute of Ethnology of the Hungarian Academy of Sciences and whose most important contribution to folkloristics was the so-called Budapest school for the study of the role of personality in storytelling, ${ }^{2}$ there were other editors whose names should be mentioned. Béla Gunda was an influential professorpedagogue, ethnologist-linguist-geographer, the chair of the Ethnography Department of the University of Debrecen, who specialized in the comparative study of the peoples of the Carpathian and Balkan areas. ${ }^{3}$ Tibor Bodrogi, also the director of the Institute of Ethnology at the Academy, was a well-known anthropologist studying the tribal art of the Pacific. The founding chair of the Department of Ethnography and Cultural Anthropology of the University of Pécs, Professor Bertalan Andrásfalvy has provided important contributions in socio-historical and environmental studies. ${ }^{4}$

Gábor Barna, former head of the Department of Ethnography and Cultural Anthropology of the University of Szeged, whose main field of interest is the folklore and anthropology of religion, served first as executive editor (since 1991/1992) and later as editor-in-chief (since 2006) of the Acta Ethnographica Hungarica for a decade. With Professor Barna, the editorial office of the journal moved from Budapest and found a new home at the University of Szeged. The journal and the Hungarian scientific community owe many thanks to Professor Barna for his 25 years of editorial work. He has taken the journal into his hand in a period when publishing lacked satisfactory financial backing. Professor Barna's perseverance, hard work, wide network of academic connections and resourcefulness helped the journal overcome the difficulties. It was also during the editorial era of Bertalan Andrásfalvy and Gábor Barna that an international advisory board of distinguished scholars was set up in 2000. The journal owes gratitude to each and every one of the members of the board for their valuable support and contribution.

We hope that it is not only our partial impression that the journal seems to have successfully fulfilled its mission. Over the 60 volumes, more than 732 research articles from Hungarian and 493 papers from foreign scholars were published in the wider field of ethnography, folklore, ethnology, social and cultural anthropology, ethno-musicology and ethno-choreology. An equal number of foreign authors came from Western and Eastern circles of scholarship. The geographic focus varied from Hungary to several European countries, from South America to Siberia, Central Asia or Oceania. The journal aptly represented the colorful traditions of the long-established discipline of Hungarian ethnographic and folklore studies.

Disciplined ethnographic investigations and interest in folklore studies reaches back to the first decades of the $19^{\text {th }}$ century in Hungary. Institutionalization occurred early

\footnotetext{
${ }^{2}$ Gyula Ortutay received, among others, the prestigious international acknowledgements of the Baumgarten (1942), Pitré (1962) and Herder (1972) prizes. He was also a deputy president of the International Society for Folk Narrative Research.

${ }^{3}$ Béla Gunda was an honorary member of the Swedish Royal Gustavus Adolphus Academy, member of several Finnish, Austrian and German scientific societies.

${ }^{4}$ Bertalan Andrásfalvy is the holder of the Swedish Sigurd Erixon Prize (1980).
} 
on and in congruence with the main wave of the rise of European ethnography and anthropology. The Hungarian Ethnographical Society was established in 1889 and is one of the oldest continuously functioning scientific societies in Europe. The periodical of the association, the Ethnographia, has been published since 1890. Systematic ethnographic museology dates back to the 1890 s, along with the birth of ethno-musicology of the grand generation of Béla Bartók and Zoltán Kodály. The pre-World-War I Kingdom of Hungary had a multiethnic population with 50\% Hungarian and 50\% non-Hungarian inhabitants, among which at least 22 co-habiting ethnicities constituted various social, religious and regional sub-groups. From the very beginning, Hungarian scholarship, in line with the makeup of the country, developed a keen interest in inter-ethnic studies and avoided ethno-centric focus. Besides the Central-European (the territory of the Austro-Hungarian Monarchy before 1920) focus, Hungarian scholars were motivated to study the origins and migrations of the nomadic ancestors of the Hungarians, which from the last decades of the $18^{\text {th }}$ century has led them to a wide range of research areas from the Volga region to Siberia, from the Urals to the Altai, from the Caucasus to Tibet or Mongolia. The ambition to trace the Hungarian language, culture and kin-folks cultivated an ethnology based on comparative methods and also enriched museum collections with invaluable objects and data, such as the unique shamanism collection. The more than 120 years of research brought together rich collections and archives. The Museum of Ethnography in Budapest owns the largest textile collection in Europe, the largest ceramics collection in Central Europe, and its Papua New Guinea, Congo and Oceania material competes with that of the most important British, French and German museums. The Hungarian Open Air Museum in Szentendre is one of the leading skanzens of Europe, not only in its size and number of buildings but also in its fresh, flexible methodology and ambitious development plan. Generations of ethno-musicologists recorded nearly 300 thousand tunes and transcribed, analyzed and systematized half of it, resulting in an unbelievably rich collection of musical tradition. In the last 70 years, they worked hand-in-hand with ethno-choreologists and dance ethnologists, collecting the incomparably rich dance material of the Carpathian basin's multiethnic traditions. While the German-oriented climate during the Monarchy brought links to German, Austrian and Swiss academia, scholars of the interwar period maintained fruitful relations with Scandinavian scholars and frequented connections with French ethnologists and Anglo-Saxon anthropologists as well. The ideologically manipulated Soviet era mandated the strengthening of relations within the Eastern bloc, but from the 1960s Hungarian scholars started to rebuild connections with Western European and American colleagues. The last quarter of a century brought new opportunities after the political democratization in 1990. A clear indication of the improvement of international networking was the $7^{\text {th }}$ SIEF (Société Internationale d'Ethnologie et de Folklore) congress held in Budapest in 2001.

The repertory of the topics of published articles in the Acta Ethnographica expresses the above sketched richness of scholarly traditions. (In the 2005 50(4):379-537, a complete bibliography of the first 50 volumes was published.)

Throughout our journal's 67 years of existence, the publishing house of the Hungarian Academy of Sciences, the Akadémiai Kiadó, took good care of and guaranteed the quality of printing. In 2013 the leadership of the Hungarian Academy of Sciences decided to regain a closer control over its periodicals and renewed the contract with the publishing house of Akadémiai Kiadó. 
Starting with the recent issue of year 2016, volume 61, the editorial work is to be executed again at the Institute of Ethnology at the Research Centre for the Humanities (RCH) of the Hungarian Academy of Sciences (HAS) in Budapest. The new editor-in-chief (Ágnes Fülemile) and the members of the editorial team (associate editor Éva Deák, review editors Csaba Mészáros and Katalin Vargha, copy editor Fruzsina Cseh, referee editor Ildikó Kristóf, layout editor Judit Komor, editorial assistants Ibolya Landgráf and Erika Illényi) are all research fellows or staff at the institute. Half of the members of the Editorial Board are on the board of directors of the same institute. Balázs Balogh, the director of the Institute of Ethnology, RCH, HAS, leads the Social Anthropology Department, Balázs Borsos is the deputy director whose main field is ecological anthropology, Ildikó Landgraf is the head of the Folklore and Ágnes Fülemile is that of the Historical Anthropology Department. Gábor Vargyas leads the Ethnology Department and as a professor represents the University of Pécs. Although the Academy's Institute of Ethnology is perhaps the most important research center of the discipline in Hungary, and with its 40 researchers is, in fact, the largest one as well, it does not mean that only the fellows of the institute receive an opportunity for publication. The editorial board of the journal is fully aware of the responsibility that they should represent the larger scientific community of ethnographers, anthropologists and folklorist in Hungary and the neighboring countries. Other members of the Editorial Board represent further important institutions of research, museology and education. Miklós Cseri, director of the Skanzen Hungarian Open Air Museum in Szentendre, Lajos Kemecsi, director of the Museum of Ethnography in Budapest, Tamás Mohay, head of the Ethnography Department of Eötvös Loránd University in Budapest, as well as Vilmos Voigt professor emeritus of folklore have all accepted board membership. Elek Bartha professor and former dean and recent pro-rector represents the University of Debrecen. László Mód has been previously working with the journal as a review editor and continues to participate in the board from the University of Szeged. Professor emeritus Attila Paládi-Kovács and László Kósa are Ordinary Members of the Hungarian Academy of Sciences and we are honored to receive their continued support.

From now on, a renewed International Advisory Board will help the work of the journal. We are grateful for Ingrid Slavec Gradišnik (head of the ZRC SAZU Institute of Slovenian Ethnology, Ljubljana), Marta Botíková (professor at the Comenius University, Bratislava), Ferenc Pozsony (professor at the Babes-Bolyai University, Cluj, Romania), Dagnoslaw Demski (senior research fellow at the Institute of Archaeology and Ethnology Polish Academy of Sciences, Warsaw), Helena Ruotsala (professor at the University of Turku, Finland), Dmitriy A. Funk (chair of the Department of Ethnology at the Lomonosov Moscow State University), Daniel Drascek (professor of Comparative European Ethnology at the University of Regensburg), Chris Hann (director of Max Planck Institute for Social Anthropology, Halle), András Zempléni (professor of the National Scientific Research Council at the Université Paris, Nanterre), Mary N. Taylor (assistant director of the Center for Place, Culture, and Politics at the Graduate Center of the City University of New York), Krista Harper (associate professor at University of Massachusetts, Amherst), and Anya Peterson Royce (chancellors' professor of Anthropology at Indiana University, Bloomington) for their willingness to participate in the work of the advisory board.

We will continue the practice of publishing two issues per year. According to our plans, out of the two issues one will be a more focused thematic issue, the other one will be a mixed issue on a variety of topics. Expert guest editors will be often invited 
to edit the special thematic issues. The articles are planned to give summaries of wellestablished research works, or analytical and methodological papers, presented with the foreign scholarly audience in mind.

The most important change from now on will be a linguistic one. In line with the increasing importance of English as the major 'lingua franca' of the international academic community, we have decided that from the previous use of four languages, the journal shifts to be a solely English-language periodical. Besides the increased accessibility for English readers, it also offers the benefit of ease of handling the translating and proofreading processes, and thus we hope to guarantee a stable linguistic quality of text. We wish to work together with three translators on a regular basis. The Australian-born Elayne Antalffy has a long-established work connection with Acta Ethnographica. Michael Kandó is a US-born Hungarian-American bi-lingual professional translator. Zsuzsanna Cselényi has moved to the US two decades ago, gained degrees at US universities, and defended her $\mathrm{PhD}$ at the Folklore Department of Indiana University in Bloomington. We are delighted that in her person we won not only an excellent translator but an expert colleague as well.

The very first issue edited by the new team will focus on ethnological studies based on fieldwork carried out in non-European areas in the last two decades by a newer generation of Hungarian scholars. The topic of ethnology was relatively underrepresented in the journal in the last two decades, and that is why it is high time to redeem our debt. Guest editors of the issue are leading scholars and professors Gábor Vargyas and Mihály Sárkány. In his introductory paper, Mihály Sárkány gives a very useful overview of the past and present of Hungarian ethnological studies and helps to contextualize the content of the present issue. More senior authors are Gábor Vargyas former and Zoltán Nagy recent head of the Ethnography and Anthropology Department of the University of Pécs. All the other authors in the present issue belong to younger generations and were students of professors Sárkány, Vargyas and Nagy in Budapest and Pécs.

Special thanks to Pál Fodor, director general of The Research Centre for the Humanities of the Hungarian Academy of Sciences, for providing extra budget for the translation of the papers of the present issue.

Ágnes Fülemile, the new editor-in-chief of the Acta Ethnographica Hungarica is a senior research fellow at the Institute of Ethnology at the $\mathrm{RCH}$ of the Hungarian Academy of Sciences, Budapest. She has MA degrees in ethnography, history and art history, MPhil in history of dress from the University of London, and a PhD in Ethnography from ELTE, Budapest. She was a Fulbright visiting scholar at the Anthropology Department of UC Berkeley (1992), the Costume Institute of The Metropolitan Museum of Art, New York (1993), and at Rutgers University (1999). In 2006-2009 she was the visiting Hungarian Chair of the Central Eurasian Studies Department at Indiana University, Bloomington. While working as the director of the Balassi Institute's Hungarian Cultural Center in New York (2012-2014), she curated the 2013 Smithsonian Folklife Festival's Hungarian Program in Washington, DC. Besides her research work, she regularly teaches American students in study abroad programs in Budapest. 